\title{
MENGENAL SOSIAL EKONOMI DI BANJARMASIN SEBAGAI SUMBER BELAJAR IPS
}

\author{
Luthfi Abdurrahman \\ Email: 1810111310011@mhs.ulm.ac.id \\ Program Studi Pendidikan Sejarah Fakultas Keguruan dan Ilmu Pendidikan \\ Universitas Lambung Mangkurat \\ Banjarmasin
}

\begin{abstract}
Abstrak
Status sosial merupakan tempat atau kedudukan seseorang dalam masyarakat dan secara umum berhubungan dengan oranglain. Untuk status ekonomi merupakan bentuk gaya hidup seseorang. Satatus sosial ekonomi keadaan atau kedudukan dalam masyarakat dari beberapa faktor, yaitu Pendidikan, pekerjaan dan pendapatan seseorang. Kota meupakan tempat sebagai pusat ekonomi, pusat pemerintahan dan untuk mendapatkan kehidupan yang lebih baik di kota. Kota Banjarmasin merupakan tempat untuk orang melakukan perdagangan. Banjarmasin adalah kota seribu sungai tidak heran semua aktivitas dilakukan di sungai-sungai. Dengan sumber belajar yang dimanfaatkan IPS dapat mampu mengenal lingkungan alamnya yang luas dan tidak terpaku pada buku saja. Sumber belajar dari masyarakat dapat menjadi relevan untuk dibicarakan karena kejadian faktual.
\end{abstract}

\section{PENDAHULUAN}

Membicarakan sejarah sosial-ekonomi di Indonesia tidak lepas dari pembicaraan tentang ekonomi perkebunan. Politik ekonomi pemerintah kolonial selama abad XIX dan XX yang bergeser dari politik dagang ke politik produksi telah menyeret penduduk pribumi dalam tata ekonomi dunia. Dalam proses tersebut, penduduk pribumi yang memiliki tanah dan tenaga kerja dipadukan dengan modal dan keterampilan yang dibawa oleh bangsa Eropa. Interaksi antara faktor tersebut mewarnai dinamika perkembangan yang terjadi pada sejarah sosialekonomi di Indonesia (Padmo, 1999: 10).

Sebutan "pulau seribu sungai" bagi Pulau Kalimantan sungguh bukan merupakan sebuah hiperbola. Pada setiap bagian dari pulau ini dijumpai sungai besar maupun kecil yang tidak sedikit jumlahnya. Demikian juga dengan Kalimantan Selatan, salah satu provinsi di Pulau Kalimantan yang pada masa Pemerintahan Kolonial Belanda bernama Zuider- en Oosterafdeling van Borneo. Banjarmasin sebagai Ibu kota Kalimantan Selatan juga mendapat julukan "kota seribu sungai" untuk menggambarkan betapa banyak dan pentingnya sungai yang mengalir di kota ini (Susilowati, 2011: 1). Sungai menjadi hal yang penting untuk masyarakat kalimanatan karena menurut (Fahrianoor, 2021), Daerah tepian sungai umumnya merupakan wilayah yang sangat subur karena endapan lumpur akibat pengaruh pasang surut air sungai. Oleh karena kesuburan tanahnya maka wilayah tepian sungai menjadi tempat konsentrasi penduduk. Ini dapat dilihat dan ditemukan sepanjang aliran sungai Martapura, Sungai Nagara 
dan Danau Panggang. Disamping itu Sungai Barito dan anak-anak sungainya, juga banyak ditemukan sungai buatan atau kanal yang disebut anjir, handil, saka. Begitu pentingnya sungai bagi masyarakat Kalimantan Selatan sehingga berkembang suatu budaya sungai, yang berpengaruh pada hampir setiap kehidupan masyarakatnya.

Hampir di seluruh negara, sejarah lahir dan tumbuhnya sebuah kota sebagai pusat pemerintahan dan perdagangan tidak terlepas dari keberadaan aliran air, baik itu berupa teluk/semenanjung ataupun cabang sungai besar. Kota Banjarmasin bertumbuh dimulai dari permukiman-permukiman vernakular yang terbentuk di sepanjang sungainya. Ratusan sungai mengelilingi dan membelah kota, dan menjadi urat nadi kehidupan masyarakatnya. Rumahrumah dibangun di tepian sungai dengan orientasi utama ke sungai, berpola linier mengikuti bentuk sungai. Sungai menjadi urat nadi kehidupan masyarakatnya. Selain sebagai lokasi bermukim, sungai juga berfungsi sebagai jalur transportasi, sumber mata pencaharian, dan menjadi pertimbangan penting dalam aktivitas keseharian masyarakatnya (Mentayani, 2016). Sungai bagi penduduk yang bermukim di tepian sungai mampu memenuhi kebutuhan dan mempertahankan hidup mereka, baik dari aspek transportasi dan mobilitas, ekonomi, sosial, budaya, dan politik. Dari konsentrasi penduduk dan interaksinya dengan sungai, maka lahirlah kebudayaan sungai. Kehidupan masyarakat Banjar berkembang di atas sungai yang menjadikan ciri khas dan budaya orang Banjar (Mentayani, 2019). Bagi masyarakat Banjarmasin, sungai bukan hanya sekedar sumber air, tetapi juga sebagai orientasi hidup dan identitas diri. Dikatakan sebagai orientasi hidup karena banyak kegiatan seharihari yang dilakukan disungai, mulai dari mandi, mencuci, menangkap ikan, berdagang, jalur transportasi hingga sebagai tempat bermain anak-anak (Afdholy, 2017).

Sumber belajar (learning source) didefinisikan sebagai informasi yang disajikan dan disimpan dalam berbagai bentuk media, yang dapat membantu peserta didik dalam belajar sebagai perwujudan dari kurikulum. Sumber belajar juga diartikan sebagai segala tempat atau lingkungan sekitar, benda, dan orang yang mengandung informasi yang dapat digunakan sebagai wahana untuk melakukan proses perubahan tingkah laku. Sumber-sumber belajar itulah yang memungkinkan kita berubah dari tidak tahu menjadi tahu, dari tidak mengerti menjadi mengerti, dan dari tidak terampil menjadi terampil. Sumber belajar IPS berarti segala sesuatu yang dapat memberi informasi kepada peserta didik, baik berupa benda, maupun orang. Sumber Belajar IPS di Sekolah dasar memiliki kesamaan dengan sumber belajar mata pelajaran yang lain. Diantara sumber balajar yang dapat digunakan dalam pembelajaran IPS, antara lain:

a) Tempat atau lingkungan alam sekitar dimana saja seseorang dapat melakukan belajar atau proses perubahan tingkah laku, misalnya : perpustakaan, pasar, museum, sungai, gunung, dan lain-lain.

b) Benda, yaitu segala benda yang memungkinkan terjadinya perubahan tingkah laku bagi peserta didik, misalnya: candi, masjid, dan sebagainya

c) Buku, yaitu segala macam jenis buku yang dapat dibaca secara mandiri oleh peserta didik, misalnya: buku pelajaran, majalah, koran, dan sebagainya

d) Peristiwa dan fakta yang sedang terjadi, misalnya kerusuhan, peristiwa bencana, dan peristiwa lainnya.

\section{PEMBAHASAN}




\section{Sosial Ekonomi di Banjarmasin}

Pengertian sosial ekonomi jarang dibahas secara bersamaan, pengertian sosial dan pengertian ekonomi sering dibahas secara terpisah. Keadaan sosial ekonomi setiap orang itu berbeda-beda, ada yang keadaan sosial ekonominya tinggi, sedang, dan rendah. Menurut Soerjono Soekanto sosial ekonomi adalah posisi seseorang dalam masyarakat berkaitan dengan orang lain dalam arti lingkungan peraulan, prestasinya, dan hak-hak serta kewajibannya dalam hubunganya dengan sumber daya. Kota menjadi peranan sebagai titik pusat pertumbuhan ekonomi serta menjadi pusat aktivitas sosial, ekonomi dan budaya. Penduduk yang pindah ke kota pada umumnya bertujuan untuk memperoleh kesempatan kerja. Hubungan tersebut mempengaruhi jumlah penduduk akibat proses urbanisasi, jumlah permintaan terhadap kebutuhan lahan yang digunakan untuk kebutuhan sosial dan ekonomi terutama permukiman juga bertambah dalam suatu perkotaan

Kehidupan sosial masyarakat sendiri terjadi karena adanya proses sosial, hal ini dikarenakan didalam masyarakat sering sekali terdapat perbedaan-perbedaan kebutuhan diantara warga atau golongan khusus suatu masyarakat yang diakibatkan oleh adanya proses sosial meliputi adat istiadat kebutuhan individu, ketegangan sosial yang muncul akibat adanya masyarakat yang menentang adat istiadat itu sendiri (Koentjaraningrat,1997:185). Kondisi kota di Indonesia berkembang pesat yang berfungsi sebagai kegiatan ekonomi telah mengundang penduduk dari daerah lain maupun pedesaan untuk mendapatkan kehidupan yang lebih baik di kota, pada umumnya kota selalu dipandang sebagai pusat kegitaan ekonomi, pusat pemerintahan, dan sebagainya. Fungsi dan peranannya atau sumber pengaruh atau sumber stimulasinya banyak berasal dari kota, kota memiliki tingkat yang tertinggi, menurut sejarah perkembangannya kota berasal dari tempat-tempat permukiman yang sangat sederhana.

Banjarmasin adalah kota seribu sungai dengan julukannya itu Banjarmasin sangat terkenal dengan sungai-sungainya, masyarakat di Banjarmasin yang sangat bergantung pada sungai seperti melakukan kegiatan mandi, mencuci, bahkan untuk melakukan perdagangan dilakukan di sungai, seperti pasar terapung yang masih ada sampai kini. Bentuk kegiatan seosial ekonomi di pasar terapung seperti Kegitan perdagangan yang dilakukan oleh perempuan. Mereka menjual hasil pertanian, perikanan, kerajinan, dan mekanan tradisional. Mereka mendapatkan produk pertanian dari lahan pertanian mereka sendiri atau membeli dari orang lain. Mereka mendapatkan ikan dari hasil tangkapan mereka sendiri di sungai atau membeli dari orang lain. Mereka mendapatkan berang-barang kerajinan tangan dari orang lain. Tidak ada pedagang adalah pengrajin. Makanan tradisional Sebagian besar dibuat oleh para pedagang (Arisanty, 2018). Pasar terapung adalah sebuah pasar tradisional yang seluruh aktivitasnya dilakukan di atas air dengan menggunakan perahu. Pasar ini melakukan transaksi di atas perahu, pedagang dan pembelinya juga tidak terpaku di suatu tempat, tetapi terus bergerak mengikuti arus sungai. pasar terapung ini disebut sebagai Pasar Balarut. Kebanyakan para pedagang adalah wanita. Menariknya, di Pasar terapung ini juga masih berlaku barter antar pedagang. Tak ada organisasi pedagang sehingga jumlah mereka yang berjualan tak terhitung.

\section{Sumber Belajar IPS}


Pendidikan IPS melibatkan kajian tentang manusia sebagai makhluk sosial, yang berinteraksi dengan sesamanya dan dengan lingkungan alam serta lingkungan sosialnya, diberbagai tempat sepanjang waktu dari masa ke masa (Putro. 2020).

Menurut Nachrawie, (2017), Sumber belajar merupakan semua sumber yang dapat dimanfaatkan untuk proses belajar mengajar, yang bisa berupa data, lingkungan, maupun kehidupan di masyarakat, baik terpisah maupun terkombinasi, sehingga dapat mempermudah peserta didik untuk mencapai tujuan pembelajaran (Putro. 2020).

Menurut Menurut Nurdin (2012) sumber belajar yang bisa dimanfaatkan dalam pembelajaran IPS diantaranya lingkungan sosial, lingkungan alam, lingkungan agama, dan lingkungan manusia. Sementara menurut sumber belajar IPS terdiri dari buku sumber, situasi dan kondisi, serta lingkungan. Pada pembelajaran IPS, buku merupakan satu-satinya sumber belajar yang dapat digunakan pada proses pembelajaran. Pada pembelajaran IPS, buku sumber bukan satu-satunya sumber pembelajaran yang dapat digunakan, karena buku sumber pada umumnya memuat informasi yang sudah lama.Media, alat peraga dan lingkungan dalam pengajaran merupakan sumber pembelajaran yang dapat membantu guru dalam melaksanakan perannya sebagai demonstrator (Putro. 2020).

lingkungan peserta didik penting untuk dijadikan sumber belajar karena sifat masyarakatyang dinamis, nyata dan lembaga-lembaga kemasyarakatan yang terus tumbuh dan berkembang, sehingga penting untuk dipelajari pada pembelajaran IPS (Putro. 2020). Manfaat lingkungan sebagai sumber belajar dapat memberikan berbagai alternatif pendekatan dalam pembelajaran yang terjadi dalam kehidupan.

\section{KESIMPULAN}

sejarah sosial-ekonomi di Indonesia tidak lepas dari pembicaraan tentang ekonomi perkebunan. Politik ekonomi pemerintah kolonial selama abad XIX dan XX yang bergeser dari politik dagang ke politik produksi telah menyeret penduduk pribumi dalam tata ekonomi dunia. Kehidupan sosial masyarakat sendiri terjadi karena adanya proses sosial, hal ini dikarenakan didalam masyarakat sering sekali terdapat perbedaan-perbedaan kebutuhan diantara warga atau golongan khusus suatu masyarakat. Kota menjadi peranan sebagai titik pusat pertumbuhan ekonomi serta menjadi pusat aktivitas sosial, ekonomi dan budaya. Dengan sumber belajar IPS bisa memanfaatkan lingkungan sebagi sumber belajar agar bisa memahami terhadap lingkungan mereka. 


\section{REFERENSI}

Afdholy, A. R. (2017). Tipomorfologi Permukiman Tepian Sungai Martapura Kota Banjarmasin. Program Pasca Sarjana Arsitektur Lingkungan Binaan-Universitas Brawijaya.

Anis, M. Z. A., Putro, H. P. N., Susanto, H., \& Hastuti, K. P. (2020). Historical Thinking Model in Achieving Cognitive Dimension of Indonesian History Learning. PalArch's Journal of Archaeology of Egypt/Egyptology, 17(7), 7894-7906

Arisanty, D., Putro, H. P. N., Normelani, E., Anis, M., \& Arifin, Z. (2018). Socioeconomic impact of Lok Baintan Floating Market as the tourism area for local community. Socio-Economic Impact of Lok Baintan Floating Market as the Tourism Area for Local Community.

Anis, M. Z. A., \& Wiyanarti, E. HISTORICAL LEARNING THROUGH THE HISTORICAL THINKING LEARNING MODEL (MPBH) BASED ON ISSUE CENTERED HISTORY BRINGS STUDENTS CAN THINK CRITICAL THINKING REALITY AND EXPECTATIONS. Jurnal Socius, 10(1), 1-11.

Fahrianoor, A. S. (2021). KONSEP BATANG BANYU PADA MASYARAKAT TEPIAN SUNGAI DALAM MENJAGA KEBERLANJUTAN SUNGAI DI KALIMANTAN SELATAN. In PROSIDING SEMINAR NASIONAL LINGKUNGAN LAHAN BASAH (Vol. 6, No. 3).

Koentjaraningrat. 1997. Pengantar Antropologi Pokok-Pokok Etnografi.Jakarta: PT Rineka Cipta

Mentayani, I. (2019, December). Identitas dan Eksistensi permukiman tepi sungai di Banjarmasin. In Prosiding Seminar Nasional Lingkungan Lahan Basah (Vol. 4, No. 3, pp. 497-502).

Mentayani, I. (2016, November). Identitas Keruangan Tepian Sungai dan Perubahannya pada Permukiman Vernakular di Banjarmasin. In Seminar Nasional-Semesta Arsitektur Nusantara (Vol. 4, pp. 17-18).

Padmo, S. (1999). Beberapa Hal Tentang Kajian Sejarah Sosial-ekonomi Indonesia: sebuah Survai. Humaniora, 11(1), 9-15.

Putro, H. P. N., \& Jumriani, J. (2020). KEHIDUPAN SOSIAL DAN EKONOMI MASYARAKAT BANTARAN SUNGAI A SEBAGAI SUMBER BELAJAR IPS.

Putro, H. P. N. (2020). Revitalisasi Nilai-Nilai Transportasi Tradisional dalam Pembelajaran IPS di Kalimantan Selatan.

Susilowati, E. PERANAN JARINGAN SUNGAI SEBAGAI JALUR PERDAGANGAN DI KALIMANTAN SELATAN PADA PAROH KEDUA ABAD XIX. Citra Lekha, (1), 1-8.

Susanto, H. (2015). Menghadirkan kelas Konstruktivis dalam Melatih Kemampuan berpikir Historis melalui model latihan Penelitian. 